\title{
Analisis faktor-faktor yang mempengaruhi pendapatan pengusaha depot air minum isi ulang di Kecamatan Tungkal Ilir Kabupaten Tanjung Jabung Barat
}

\author{
Surya Asnelly*; Siti Hodijah; Candra Mustika \\ Prodi Ekonomi Pembangunan, Fak. Ekonomi dan Bisnis, Universitas Jambi \\ *E-mail korespodensi: suryaasnelly@gmail.com
}

\begin{abstract}
This study aims to analyze the socio-economic characteristics of refill drinking water depot entrepreneurs and analyze the influence of opinions of refill drinking water depot entrepreneurs in Tungkal Ilir District, Tanjung Jabung Barat Regency. The data used in this study is primary data obtained through field research sourced from refill drinking water depot entrepreneurs as samples. The sampling method used in this study is Stratified Random Sampling. The analysis tool uses multiple linear regression. Based on the socio-economic characteristics of refill drinking water depot entrepreneurs in Tungkal Ilir District, Tanjung Jabung Barat Regency, some differences can be seen from the majority group of respondents based on the majority gender, age, education level, number of family members, length of business and income of refilled drinking water depot entrepreneurs repeat. The results of data processing the payment of refill drinking water depot entrepreneurs will increase obtained from the regression coefficients of each tube machine variable, education level, and family dependents, which significantly affect the income of refill drinking water depot entrepreneurs. At the same time, the operating hours variable has no significant effect on the payment of refill drinking water depot entrepreneurs in Tungkal Ilir District, Tanjung Jabung Barat Regency.
\end{abstract}

Keywords : Income, Characteristics of refill drinking water depot entrepreneurs.

\begin{abstract}
Abstrak
Penelitian ini bertujuan untuk menganalisis karakteristik sosial ekonomi pengusaha depot air minum isi ulang dan menganalisis pengaruh pendapat pengusaha depot air minum isi ulang di Kecamatan Tungkal Ilir Kabupaten Tanjung Jabung Barat. Data yang digunakan dalam penelitian ini adalah data primer yang diperoleh dengan cara penelitian lapangan yang bersumber dari pengusaha depot air minum isi ulang sebagai sampel. Metode penarikan sampel yang digunakan dalam penelitian ini adalah Stratified Random Sampling. Alat analisis menggunakan regresi linier berganda. Berdasarkan karakteristik sosial ekonomi pengusaha depot air minum isi ulang di Kecamatan Tungkal Ilir Kabupaten Tanjung Jabung Barat terdapat perbedaan yang dapat dilihat dari kelompok responden mayoritas berdasarkan jenis kelamin mayoritas, umur, tingkat pendidikan, jumlah anggota keluarga, lama usaha dan pendapatan pengusaha depot air minum isi ulang. Hasil pengolahan data pendapatan pengusaha depot air minum isi ulang akan meningkat diperoleh dari koefisien regresi masing-masing variabel mesin tabung, tingkat pendidikan dan tanggungan keluarga yang berpengaruh signifikan terhadap pendapatan pengusaha depot air minum isi ulang. Sedangkan variabel jam operasional tidak berpengaruh signifikan terhadap pendapatan pengusaha depot air minum isi ulang di Kecamatan Tungkal Ilir Kabupaten Tanjung Jabung Barat.
\end{abstract}


Kata kunci: Pendapatan, karakteristik pengusaha depot air minum isi ulang.

\section{PENDAHULUAN}

Air merupakan kebutuhan yang sangat penting bagi kehidupan manusia. Air digunakan untuk berbagai macam kebutuhan diantaranya minum, mandi, mencuci dan memasak. Kebutuhan air semakin lama semakin meningkat sesuai dengan keperluan dan taraf kehidupan penduduk. Salahs satu kebuthan utama dalam kehidupan makhluk hidup adalah air. Air diperlukan oleh makhluk hidup untuk digunakan dalam berbagai keperluan seperti mandi, memasak dan mencuci. adalah 30 - 60 liter/ orang/ hari, kebutuhan air di negara - negara maju memerlukan 60 - 120 liter/ orang/ hari (Suyono dan Budiman, 2010).

Kebutuhan air juga semakin bertambah seiring dengan meningkatnya jumlah penduduk. Tingginya tingkat pencemaran air menjadi salah satu masalah dalam pengolahan air. Berbagai macam upaya dilakukan terus menerus untuk (Radji dkk, 2008). Menurut Purwanto (1995), air adalah sumber daya alam yang sangat diperlukan dalam kehidupan dan merupakan unsur utama dalam setiap sistem lingkungan hidup, baik bagi manusia, tanaman, hewan dan juga bagi pertanian, industri dan bagi keseimbangan. Air sangat berperan dalam upaya peningkatan kesejahteraan masyarakat, sebagaimana ditetapkan dalam pasal 33 ayat 3 UUD 1945 yang berbunyai "Bumi dan air kekayaan alam yang terkandung didalamnya dikuasai oleh negara dan dipergunakan untuk sebesar-besarnya kemakmuran rakyat". Secara teoritis kesdiaan air di bumi ini jumlah atau volumenya tidak bertambah. Dengan kata lain, kuantitas sumber daya air di bumi adalah tetap. Total volume air di bumi adalah sekitar 1,4\% milyar kilometer kubik, yang terdiri dari 97,3\% air laut dan 2,7\% air tawar yang terdapat didaratan $(37,8$ juta kilometer kubik) yang berbentuk lapisan es di gunung - gunung dan gietser $(77,3 \%)$, air tanah serapan $22,4 \%$, air danau dan rawa - rawa 0,35\%, uap air di atmosfer bumi $0,04 \%$ serta air sungai 0,01\% (Salim, 1991).

Berdasarkan konsensus Millineum Development Goals (MDGs) untuk tahun 2019 kebutuhan air bersih minimal untuk wilayah perkotaan adalah $80 \%$ dan di wilayah pedesaan 60\%. Dengan adanya target dari MDGs tersebut diperlukan langkah antisipasif dengan melakukan indifikasi secara keseluruhan kondisi pelayanan, sumber air baku, sistem produksi, sistem distribusi dan kinerja PDAM. Kinerja (performance) merupakan gambaran mengenai sasaran, tujuan misi dan visi organisasi yang tertuang dalam strategic planning suatu tingkat pelaksanaan suatu kegiatan/ program/ kebijakan dalam mewujudkan organisasi yang baik.

Diperkirakan sekitar 321 juta jiwa penduduk Indonesia akan mengalami kelangkaan air bersih pada tahun 2025. Pertumbuhan penduduk yang tidak sebanding dengan ketersediaan air dan perilaku masyarakat yang boros air menjadi penyebab utamanya. Penggunaan air dalam kegiatan rumah tangga sehari - hari merupakan salah satu faktor yang menyebabkan akan terjadinya krisis air bersih di Indonesia. Pemakaian air rata - rata rumah tangga di perkotaan di Indonesia untuk golongan ekonomi menengah ke bawah adalah 169,11 liter per orang per hari. Sementara untuk golongan ekonomi menengah ke atas adalah 247,36 liter per orang per hari untuk kegiatan sehari - hari seperti mencuci tangan, menggosok gigi, mandi, toilet, mencuci baju, mencuci piring, memasak, menyiram tanaman dan mencuci kendaraan (Republika, 2019).

Menurut Sudaryanto (2009), konsekuensi meningkatnya kebutuhan air bersih ini berarti bahwa permintaan agregat (Agregat Demand) pasti akan naik, sementara penawaran agregat (Agregat Supply) relatif konstan bahkan dapat dikatakan menurun jika faktor pencemaran turut diperhitungkan. Sesuai pendapat Simanjuntak (2001), 
bahwa Indonesia sekarang ini sedang mengalami proses penggunaan air yang berlangsung dengan laju kecepatan yang lebih besar dari proses penyimpanan air. Tingkat kebutuhan akan air bersih terutama di kota - kota besar terus meningkat. Adanya peningkatan ini dapat diketahui dari analisis statistik air minum yang dikeluarkan oleh Biro Pusat Statistik 2019 yang menunjukkan bahwa dari tahun ke tahun kuantitas persediaan air bersih terus meningkat, tetapi masih belum dapat memenuhi kebutuhan penduduk di kota besar, yang disebabkan oleh adanya laju Urbanisasi dan aktivitas ekonomi yang tinggi.

Menurut Sutrisno (2002), pemanfaatan air dilakukan oleh berbagai sektor ekonomi, antara lain rumah tangga, industri, infrasruktur. Permasalahannya bagaimana cara pendistribusian air dan persediaan yang ada ke berbagai sektor tersebut dapat memperoleh manfaat sosial optimal, serta tidak digunakan secara berlebihan. Pada kenyataannya, kuantitas air tidak mungkin dapat ditingkatkan, sedangkan tingkat penyebarannya dalam waktu dan runag tidak merata sesuai dengan kebutuhan sebenarnya. Standar kebutuhan air bersih untuk rumah tangga di daerah perkotaan didasarkan standar untuk kebutuhan daerah yang belum relevan dengan penyesuaian terhadap kondisi kota yang bersangkutan.

Kabupaten Tanjung Jabung Barat merupakan daerah dengan mayoritas wilayahnya tanah gambut yang sulit sekali untuk mendapatkan air bersih. Perusahaan Daerah Air Minum (PDAM) sebagai distributor air bersih. Maka permintaan akan air bersih dari masyarakat masih cukup banyak yang harus dipenuhi PDAM. Kebutuhan akan air bersih sangat mendasar bagi masyarakat Kabupaten Tanjung Jabung Barat sehingga bisa mencapai 36 juta liter kubik per bulan. Dari tahun ke tahun pemenuhan air bersih oleh PDAM Tirta Pengabuan selalu meningkat sesuai jumlah pemasaran pelanggan (BPS, Tanjab Barat, 2019).

Kabupaten Tanjung Jabung Barat pada tahun 2009 telah menyumbangkan air bersih PDAM Tirta Pengabuan pada pelanggan - pelanggan sekitar 1.287 kepala keluarga, hingga pada 10 tahun kemudian tahun 2019 pelanggan air bersih PDAM Tirta Pengabuan telah menyambungkan kepada pelanggan sebanyak 14.480 kepala keluarga yang tersambung. Jumlah pelanggan air bersih PDAM Tirta Pengabuan masih sangat jauh dari target pemerintah daerah sebanyak 27.781 kepala keluarga yang tersambung. Kebutuhan air bersih rata-rata 169,11 liter kubik per orang per hari, sehingga dalam setiap rumah tangga akan membutuhkan air bersih mencapai 400 liter kubik. Upaya PDAM Tirta Pengabuan memperluas jangkauan pipa - pipa keseluruh jalan - jalan terus dikerjakan dengan memakai proyek anggaran pemerintah daerah. Namun kendala dilapangan masih selalu menjadi penghalang penyambungan.

Kabupaten Tanjung Jabung Barat telah mengeluarkan PERDA Nomor : 18 Tahun 2006 tentang perubahan atas peraturan daerah Kabupaten Dati II Tanjung Jabung Nomor : 02 Tahun 1993 tentang susunan organisasi dan data kerja PDAM Tirta Pengabuan Kabupaten Dati II Tanjung Jabung. Peraturan Daerah sebagai pembentukan PDAM Tirta Pengabuan Kabupaten Tanjung Jabung Barat yang tersusun dari organisasi, pengawasan, dan operasional PDAM Tirta Pengabuan secara profesiona dan transparan. Pemerintah Kabupaten Tanjung Jabung Barat juga telah mengeluarkan PERDA Nomor : 50 Tahun 2001 tentang tarif air minum dan non air minum pada perusahaan daerah air minum. Peraturan pemerintah daerah ini mengacu pada susunan anggaran dan penerimaan dari pelayanan terhadap pelanggan PDAM Tirta Pengabuan. Berdasarkan PERDA tersebut, pelanggan lebih gampang mengatur pemakaian PDAM untuk konsumsi sehari - hari karena telah mengetahui tarif dasar pemakaian (BPS Tanjab Barat, 2019). 
Kecamatan Tungkal Ilir merupakan Ibu Kota Kabupaten Tanjung Jabung Barat yang populasi pertumbuhan jumlah penduduk selalu meningkat dari sebelumnya 2,3 persen pada tahun 2018. Geografi Kecamatan Tungkal Ilir mempunyai luas wilayah $99,11 \mathrm{Km}^{2}$ dengan jumlah penduduk 72.460 jiwa pada tahun 2019. Dengan jumlah penduduk Kecamatan Tungkal Ilir yang besar mendorong juga pada akan permintaan air bersih untuk memenuhi kebutuhan sehari - hari. Kendati besarnya harapan masyarakat Kecamatan Tungkal Ilir akan pelayanan PDAM Tirta Pengabuan bisa tersalurkan kepada mereka yang berada di pusat kota, namun masih banyak sekali kendala yang dihadapi terutama air yang dihasilkan tidak layak untuk diminum (BPS Tungkal Ilir, 2019).

Keadaan ini membuat terobosan bagi masyarakat Kecamatan Tungkal Ilir untuk membuat usaha depot air minum isi ulang. Keberadaan depot air minum isi ulang yang tersebar di seputaran wilayah Kecamatan Tungkal Ilir masih belum mampu memenuhi kebutuhan minum masyarakat secara hygienis, namun setidaknya mampu menjadikan solusi sementara untuk memenuhi kebutuhan air minum.

\section{METODE}

Metode penelitian adalah pengetahuan tentang cara-cara atau metode-metode atau desain atau tehnik yang diterapkan dalam melaksanakan suatu penelitian. Dengan demikian, metode penelitian adalah ilmu pengetahuan tentang berbagai cara atau metode atau tehnik yang dipergunakan dalam melaksanakan suatu penelitian ilmiah, Amir, Yulmardi dan Junaidi (2009). Metode penelitian yang digunakan dalam penelitian ini menggunakan data primer. Data primer adalah data yang diambil langsung pada masyarakat dengan menggunakan kuisionaer dan hasil obsirvasi.

\section{Jenis data}

Data yang digunakan dalam penelitian ini terdiri dari dua jenis data yaitu jenis data primer dan data sekunder.

\section{Data primer}

Data primer adalah suatu data-data yang diambil langsung oleh sumbernya, tanpa ada perantara sumber yang dimaksud dapat berupa benda, situasi, atau manusia. Adapun data primer yang di peroleh melalui observasi langsung dari hasil angket dengan di sebarkannya pada responden buruh bongkar muat sesuai dengan keperluan analisis dan tujuan penelitian. Data yang dibutuhkan dalam penelitian ini adalah identitas pengusaha depot air minum isi ulang sebagai sampel yang meliputi : nama, umur, tingkat pendidikan, tanggungan keluarga, dan data-data lain yang terkait dengan penelitian ini.

Data Sekunder

Data sekunder berupa data yang diperoleh dari instansi pihak terkait yang merupakan hasil olahan dari pihak tersebut.

\section{Sumber data}

Sumber data adalah subjek data yang diperoleh. Adapun yang menjadi sumber data dalam penelitian ini adalah pendapatan pengusaha depot air minum isi ulang yang membuka usahanya di Kecamatan Tungkal Ilir Kabupaten Tanjung Jabung Barat. 


\section{Metode angket (kuisioner)}

Kuisioner yaitu suatu pengumpulan data dengan memberikan atau menyebarkan daftar partanyaan ataupun pernyataan kepada responden dengan harapan responden merespon daftar pertanyaan atau pernyataan tersebut. Instrumen dalam penelitian ini bersifat terbuka dan tertutup. Pertanyaan terbuka adalah jika jawaban tidak disediakan sebelumnya, sedangkan pertanyaan tertutup adalah jika alternatif-alternatif jawaban telah disediakan (Umar, 2003).

\section{Wawancara}

Wawancara yaitu pengumpulan data dengan cara melakukan tanya jawab dengan pengusaha depot air minum isi ulang di Kecamatan Tungkal Ilir Kecamatan Tungkal Ilir Kabupaten Tanjung Jabung Barat dengan maksud mendapatkan informasi tentang data-data yang diperlukan dalam menunjang penelitian ini. Dalam wawancara dengan pengusaha depot air minum isi ulang dilakukan secara persuasif dengan turun langsung dilapangan.

\section{Metode penarikan sampel}

Menurut Sugiyono (2011), Populasi adalah wilayah generalisasi yang terdiri atas objek atau subjek yang mempunyai kualitas dan karakteristik tertentu yang ditetapkan oleh peneliti untuk dipelajari dan kemudian ditarik kesimpulannya. Daerah penelitian yang dipilih adalah pengusaha depot air minum isi ulang di Kecamatan Tungkal Ilir.

Tabel 1. Depot air minum isi ulang di Kecamatan Tungkal Ilir

\begin{tabular}{|c|c|c|}
\hline Desa/Kelurahan & Depot Air Minum & Responden \\
\hline Teluk Sialang & 5 & 2 \\
\hline Tungkal I & 7 & 4 \\
\hline Tungkal II & 16 & 6 \\
\hline Tungkal III & 10 & 5 \\
\hline Tungkal IV Kota & 23 & 9 \\
\hline Tungkal Harapan & 17 & 6 \\
\hline Kampung Nelayan & 36 & 12 \\
\hline Patunas & 15 & 6 \\
\hline Sriwijaya & 16 & 6 \\
\hline Sungai Nibung & 7 & 4 \\
\hline Jumlah & 152 & 60 \\
\hline
\end{tabular}

Sumber : Data diolah, 2019

Pada penelitian ini akan diambil sampel secara sengaja (purposive) sebanyak 152 pengusaha depot air minum isi ulang sebagai responden. Ukuran sampel diperoleh dengan menggunakan rumus Slovin, yaitu :

$n=\frac{\mathrm{N}}{1+\mathrm{N} \cdot \mathrm{e}^{2}}$

Dimana : 
$\mathrm{n} \quad=$ Ukuran Sampel

$\mathrm{N}=$ Ukuran Populasi

$\mathrm{e}=$ Persen kelonggaran ketidaktelitian karena kesalahan (5\%)

Berdasarkan dari rumus Slovin tersebut, maka jumlah sampel yang diambil dari populasi pengusaha depot air minum isi ulang di Kecamatan Tungkal Ilir adalah sebanyak 152 orang yaitu sebagai berikut :

$n=\frac{\mathrm{N}}{1+\mathrm{N} \cdot \mathrm{e}^{2}}$

$n=\frac{152}{1+152 \cdot(0,1)^{2}}$

$n=\frac{152}{1+1,52}$

$n=\frac{152}{2,52}$

$n=60,03$ responden

Jadi pada penelitian ini di pilih sampel sebanyak 60 orang responden, dimana dari 60 responden tersebut tersebar di Kecamatan Tungkal Ilir. Dalam penelitian ini teknik pengambilan sampel dilakukan secara acak sederhana (Random Sampling).

\section{Analisis deskriptif}

Analisis deskriftif berhubungan dengan pengumpulan dan peringkasan data, serta penyajian hasil peringkasan tersebut. Analisis Deskriftif sangat bermanfaat untuk menganalisis data populasi atau untuk menganalisis kajian atau penelitian yang obyeknya berupa populasi. Analisis Deskriftif adalah suatu metode yang berfungsi untuk membuat gambaran secara sistematis dan faktual mengenai fakta-fakta yang ada dilapangan dengan berdasarkan kepada teori-teori, konsep-konsep, yang ada diliteratur yang terkait dengan penelitian ini. Dimana prosedur gejala dan hubungan-hubungannya definisikan, diklasifikasikan, dan dikategorikan. Karateristik sosial ekonomi yang dimaksud adalah umur, tingkat pendidikan, curahan jam kerja, dan tanggungan keluarga.

\section{Analisis kuantitatif}

Apabila data yang dikumpulkan itu berjumlah besar dan mudah diklasifikasi ke dalam kategori-kategori tertentu, maka analisis kuantitatiflah yang harus dikerjakan. Analisis kuantitatif itu di sebut juga analisis statistik, bagaimanpun juga adalah kegiatan yang dituntun secara sadar oleh disiplin, kecermatan dan ketelitian. Namun demikian hendaklah diingat bahwa kelebihan dalam hal kecermatan (accuracy) ini tidaklah berarti bahwa pada analisis kuantitatif itu selalu ada kelebihan dalam hal derajat kebenarannya (validity) apabila pengolahan data, penggunaan data tidak tepat.

\section{Alat analisis data}

\section{Analisis regresi linier berganda}

Regresi linier berganda dapat dimanfaatkan untuk mengetahui bagaimana variabel dependen (kriteria) dapat diprediksi melalui variabel independen (prediktor). Dampak dari penggunaan analisis regresi dapat digunakan untuk memutuskan apakah naik atau menurunnya variabel dependen dan dapat juga dilakukan melalui menaikkan dan menurunkan keadaan variabel independen (Umar, 2003). Sedangkan untuk 
menghetahui pendapatan tenaga kerja, dibuatlah kuesioner yang berisi pertanyaanpertanyaan, penilaian responden tentang modal, luas lahan dan tenga kerja yang dilontarkan oleh peneliti. Untuk mengetahui besarnya pengaruh variabel bebas secara parsial maupun bersama-sama terhadap variabel terikat dalam penelitian ini mengunakan analisis Eviews 8.1, juga menggunakan analisis persamaan regresi linier berganda sebagai berikut : (Firdaus, 2011).

$Y=a+\beta_{1} X_{1}+\beta_{2} X_{2}+\beta_{3} X_{3}+\beta 4 X_{4}+e$

Penelitian ini dapat diterapkan sesuai dengan rumus (2) yang dimodifikasi menjadi Pendapatan $=f(\mathrm{MT}, \mathrm{JO}, \mathrm{TP}, \mathrm{TK})$ atau lebih lanjut dapat dirumuskan menjadi

$$
\mathrm{Y}=\mathbf{a}+\beta 1 \mathrm{MT}+\beta 2 \mathrm{JO}+\beta 3 \mathrm{TP}+\beta 4 \mathrm{TK}+\varepsilon
$$

Dimana :

$\mathrm{Y} \quad=$ Pendapatan pengusaha depot air minum

$\mathrm{a} \quad=$ Konstanta

$\beta=$ Koofisien regresi

MT = Mesin tabung

$\mathrm{JO}=$ Jam operasional

$\mathrm{TP}=$ Tingkat pendidikan

$\mathrm{TK}=$ Tanggungan keluarga

$\varepsilon \quad=$ Standar error

HASIL DAN PEMBAHASAN

Karakteristik responden berdasarkan jenis kelamin

Karakteristik responden berdasarkan jenis kelamin pengusaha depot air minum isi ulang di Kecamatan Tungkal Ilir Kabupaten Tanjung Jabung Barat dapat dilihat pada Tabel 2.

Tabel 2. Karakteristik responden berdasarkan jenis kelamin

\begin{tabular}{ccc}
\hline Jenis kelamin & Jumlah responden & Persentase (\%) \\
\hline Laki-laki & 42 & 70,00 \\
Perempuan & 18 & 30,00 \\
\hline Total & $\mathbf{6 0}$ & $\mathbf{1 0 0 , 0 0}$ \\
\hline
\end{tabular}

Sumber : Data diolah, 2019

Berdasarkan Tabel 2. menjelaskan bahwa dari 60 responden pengusaha depot air minum isi ulang di Kecamatan Tungkal Ilir Kabupaten Tanjung Jabung Barat dengan jenis kelamin laki-laki menunjukkan jumlah sebanyak 42 orang atau 70,00\%, sedangkan yang berjenis perempuan sebanyak 18 orang atau 30,00\%. Hal ini menunjukkan bahwa sebagian besar responden/ pengusaha depot air minum isi ulang dalam penelitian ini adalah jenis kelamin laki-laki.

\section{Karakteristik responden berdasarkan umur}

Karakteristik responden berdasarkan umur pengusaha depot air minum isi ulang di Kecamatan Tungkal Ilir Kabupaten Tanjung Jabung Barat dapat dilihat pada Tabel 3.

Tabel 3. Karakteristik responden berdasarkan umur 


\begin{tabular}{ccc}
\hline Umur (tahun) & Jumlah responden & Persentase (\%) \\
\hline $20-30$ & 14 & 23,33 \\
$31-40$ & 22 & 36,67 \\
$\geq 41$ & 24 & 40,00 \\
\hline Total & $\mathbf{6 0}$ & $\mathbf{1 0 0 , 0 0}$ \\
\hline
\end{tabular}

Sumber : Data diolah, 2019

Berdasarkan Tabel 3. menjelaskan bahwa dari 60 responden pengusaha depot air minum isi ulang di Kecamatan Tungkal Ilir Kabupaten Tanjung Jabung Barat dengan umur 2 - 30 tahun menunjukkan jumlah sebanyak 14 orang atau 23,33\%, dan umur 31 - 40 tahun sebanyak 22 orang atau $36,67 \%$, sedangkan yang umur $\geq 41$ tahun sebanyak 24 orang atau $40,00 \%$. Hal ini menunjukkan bahwa sebagian besar responden/ pengusaha depot air minum isi ulang dalam penelitian ini adalah dari umur di atas 41 tahun.

\section{Karakteristik responden berdasarkan tingkat pendidikan}

Karakteristik respon berdasarkan tingkat pendidikan yang menjadi pengusaha depot air minum isi ulang di Kecamatan Tungkal Ilir Kabupaten Tanjung Jabung Barat dapat dilihat pada Tabel 4.

Tabel 4. Karakteristik responden berdasarkan tingkat pendidikan

\begin{tabular}{ccc}
\hline Tingkat pendidikan & Jumlah responden & Persentase (\%) \\
\hline SD & 3 & 5,00 \\
SLTP & 11 & 18,33 \\
SLTA & 20 & 33,33 \\
S1 & 26 & 43,34 \\
\hline Total & $\mathbf{6 0}$ & $\mathbf{1 0 0 , 0 0}$
\end{tabular}

Sumber : Data diolah, 2019

Berdasarkan Tabel 4. menjelaskan bahwa dari 60 responden pengusaha depot air minum isi ulang di Kecamatan Tungkal Ilir Kabupaten Tanjung Jabuung Barat dengan tingkat pendidikan SD, SLTP, dan SLTA dan tingkat perguruan tinggi (S1) semuanya menjadi responden, dengan responden tingkat pendidikan SD menunjukkan jumlah sebanyak 3 orang atau 5,00\%, tingkat pendidikan SLTP berjumlah 11 orang atau $18,33 \%$, tingkat pendidikan SLTA berjumlah 20 orang atau 33,33\% dan tingkat pendidikan perguruan tinggi untuk S1 sebanyak 26 orang atau 43,34\%. Hal ini menunjukkan bahwa sebagian besar responden dalam penelitian ini adalah dari tingkat pendidikan S1.

\section{Karakteristik responden berdasarkan jumlah anggota keluarga}

Karakteristik responden berdasarkan jumlah anggota keluarga yang menjadi pengusaha depot air minum isi ulang di Kecamatan Tungkal Ilir Kabupaten Tanjung Jabung Barat dapat dilihat pada Tabel 5.

Tabel 5. Karakteristik responden berdasarkan jumlah anggota keluarga

\begin{tabular}{ccc}
\hline Jumlah anggota keluarga & Jumlah responden & Persentase (\%) \\
\hline $1-2$ & 20 & 33,33 \\
$3-4$ & 22 & 36,67 \\
$5-6$ & 10 & 16,67 \\
$7-$ keatas & 8 & 13,33 \\
\hline
\end{tabular}




\begin{tabular}{ccc}
\hline Total & $\mathbf{6 0}$ & $\mathbf{1 0 0 , 0 0}$ \\
\hline Sumber : Data diolah, 2019 & &
\end{tabular}

Berdasarkan Tabel 5. menjelaskan bahwa dari 60 responden pengusaha depot air minum isi ulang di Kecamatan Tungkal Ilir Kabupaten Tanjung Jabung Barat dengan jumlah anggota keluarga 1-2 menunjukkan jumlah sebanyak 20 orang atau 33,33\%, sedangkan jumlah anggota keluarga 3-4 sebanyak 22 orang atau 36,67\%, jumlah anggota keluarga 5-6 sebanyak 10 orang atau 16,67\% jumlah anggota keluarga 7 keatas sebanyak 8 orang atau $13,33 \%$. Hal ini menunjukkan bahwa sebagian besar responden dalam penelitian ini adalah jumlah anggota keluarga dengan 3-4 orang.

\section{Karakteristik responden berdasarkan lama usaha}

Karakteristik responden berdasarkan lama usaha pengusaha depot air minum isi ulang di Kecamatan Tungkal Ilir Kabupaten Tanjung Jabung Barat dapat dilihat pada Tabel 6.

Tabel 6. Karakteristik responden berdasarkan lama usaha

\begin{tabular}{ccc}
\hline Lama usaha (tahun) & Jumlah responden & Persentase (\%) \\
\hline $1-10$ & 33 & 55,00 \\
$11-20$ & 22 & 36,67 \\
$21-30$ & 5 & 8,33 \\
\hline Total & $\mathbf{6 0}$ & $\mathbf{1 0 0 , 0 0}$ \\
\hline
\end{tabular}

Sumber : Data diolah, 2019

Berdasarkan Tabel 6 menjelaskan bahwa dari 60 responden pengusaha depot air minum isi ulang di Kecamatan Tungkal Ilir Kabupaten Tanjung Jabung Barat dengan lama usaha 1 - 10 tahun menunjukkan jumlah sebanyak 33 orang atau $55,00 \%$, dan lama usaha 11 - 20 tahun sebanyak 22 orang atau $36,67 \%$, sedangkan yang lama usaha 21 - 30 tahun sebanyak 5 orang atau 8,33\%. Hal ini menunjukkan bahwa sebagian besar responden dalam penelitian ini adalah dilihat dari lama usaha $1-10$ tahun.

\section{Karakteristik responden berdasarkan pendapatan pengusaha depot air minum isi ulang}

Karakteristik responden berdasarkan pendapatan pengusaha depot air minum isi ulang di Kecamatan Tungkal Ilir Kabupaten Tanjung Jabung Barat dapat di lihat sebagai berikut :

Tabel 7. Karakteristik responden berdasarkan pendapatan pengusaha depot air minum isi ulang

\begin{tabular}{ccc}
\hline $\begin{array}{c}\text { Pendapatan pengusaha depot air } \\
\text { minum isi ulang (Rp) }\end{array}$ & Jumlah responden & Persentase (\%) \\
\hline $2.000 .000-3.000 .000$ & 17 & 28,33 \\
$3.100 .000-4.000 .000$ & 33 & 55,00 \\
$\geq 4.100 .000$ & 10 & 16,67 \\
\hline Total & $\mathbf{6 0}$ & $\mathbf{1 0 0 , 0 0}$ \\
\hline
\end{tabular}

Sumber : Data diolah, 2019

Berdasarkan Tabel 7 menjelaskan bahwa dari 60 responden pengusaha depot air minum isi ulang di Kecamatan Tungkal Ilir Kabupaten Tanjung Jabuung Barat dengan 
pendapatan Rp 2.000.000 - 3.000.000,- menunjukkan jumlah sebanyak 17 orang atau $28,33 \%$, dan pendapatan Rp 3.100.000 - 4.000.000,- sebanyak 37 orang atau 55,00\%, sedangkan yang pendapatan Rp 4.100.000 keatas sebanyak 10 orang atau 16,67\%. Hal ini menunjukkan bahwa sebagian besar responden/ pengusaha depot air minum isi ulang dalam penelitian ini adalah dari pendapatan Rp 3.100.000 - 4.000.000,--

Pendapatan pengusaha depot air minum isi ulang dalam penelitian ini adalah pendapatan bersih selama satu bulan. Pendapatan bersih adalah pendapatan yang telah dipotong dari biaya-biaya seperti listrik, supply air bersih, tisu botol, dan upah karyawan. Pengusaha depot air minum isi ulang menyediakan tempat pembelian secara langsung maupun secara pesan antar kerumah (request for delivery).

Faktor-faktor yang mempengaruhi pendapatan pengusaha depot air minum isi ulang di Kecamatan Tungkal Ilir Kabupaten Tanjung Jabung Barat.

Hasil pengolahan regresi linier berganda dengan Eviews versi 9.0 bertujuan untuk menentukan faktor-faktor yang mempengaruhi pendapatan pengusaha depot air minum isi ulang di Kecamatan Tungkal Ilir Tanjung Jabung Barat. Adapun faktorfaktor yang mempengaruhi tersebut adalah mesin tabung, jam operasional, tingkat pendidikan dan tanggungan keluarga sesuai Tabel 8.

Tabel 8. Hasil regresi linier berganda

\begin{tabular}{lrrrr}
\hline \multicolumn{1}{c}{ Variable } & \multicolumn{1}{c}{ Coefficient } & \multicolumn{1}{c}{ Std. Error } & \multicolumn{1}{c}{ t-Statistic } & \multicolumn{1}{c}{ Prob. } \\
\hline C & -1188336. & 438094.2 & -2.712514 & 0.0089 \\
Mesin Tabung (MT) & 269477.4 & 116356.6 & 2.315962 & 0.0243 \\
Jam Operasional (JO) & 58963.84 & 55171.85 & 1.068731 & 0.2899 \\
Tingkat Pendidikan (TP) & 148272.1 & 42060.78 & 3.525186 & 0.0009 \\
Tanggungan Keluarga (TK) & 294857.1 & 70673.30 & 4.172115 & 0.0001 \\
R-squared & 0.730020 & F-statistic & 37.17978 \\
Adjusted R-squared & 0.710386 & Prob(F-statistic) & 0.000000 \\
\hline
\end{tabular}

Sumber : Data diolah, 2019

Hasil pengolahan data dengan menggunakan Eviews versi 9.0 di peroleh regresi linier berganda dengan persamaan regresi sebagai berikut :

$$
\begin{aligned}
& Y=a+\beta_{1} X_{1}+\beta_{2} X_{2}+\beta_{3} X_{3}+\beta_{4} X_{4}+e \\
& Y=-1188336.0+269477.4 M T+58963.84 J O+148272.1 T P+294857.1 T K
\end{aligned}
$$

Hasil pengolahan data di peroleh bahwa variabel mesin tabung, tingkat pendidikan dan tanggungan keluarga yang berpengaruh signifikan terhadap pendapatan pengusaha depot air minum isi ulang di Kecamatan Tungkal Ilir dengan tingkat probabilita di bawah 5\% $(\alpha=0,05)$. Sedangkan variabel jam operasional tidak berpengaruh signifikan terhadap pendapatan pengusaha depot air minum isi ulang di Kecamatan Tungkal Ilir karena tingkat probabilitanya di atas 5\% $(\alpha=0,05)$.

Diketahui bahwa hasil pengolahan data dengan menggunakan regresi linier berganda adalah sebagai berikut : (1) Nilai konstanta sebesar -1188336.0 yang berarti jika mesin tabung, jam operasional, tingkat pendidian dan tanggungan keluarga tetap maka pendapatan pengusaha depot air minum isi ulang di Kecamatan Tungkal Ilir sebesar Rp 1.188.336,0. (2) Koefisien regresi mesin tabung sebesar 269477.4 maka apabila mesin tabung mengalami peningkatan 1 buah maka pendapatan pengusaha depot air minum isi ulang di Kecamatan Tungkal Ilir sebesar Rp 269.477,4. (3) Koefisien regresi jam operasional sebesar 148272.1 maka apabila jam operasional 
mengalami penambahan sebesar 1 jam maka pendapatan pengusaha depot air minum isi ulang di Kecamatan Tungkal Ilir sebesar Rp 148.272,4. (4) Koefisien regresi tingkat pendidikan sebesar 148272.1 maka apabila tingkat pendidikan mengalami penambahan sebesar 1 tingkat maka pendapatan pengusaha depot air minum isi ulang di Kecamatan Tungkal Ilir sebesar Rp 148.272,1. (5) Sedangkan Koefisien regresi tanggungan keluarga sebesar 294857.1 maka apabila tanggungan keluarga mengalami penambahan sebesar 1 orang maka pendapatan pengusaha depot air minum isi ulang di Kecamatan Tungkal Ilir sebesar Rp 294.857,1.

Berdasarkan hasil pengolahan data pendapatan pengusaha depot air minum isi ulang akan meningkat diperoleh dari koefisien regresi masing-masing variabel mesin tabung sebesar 269477.4, tingkat pendidikan sebesar 148272.1, dan tanggungan keluarga sebesar 294857.1 yang berarti variabel mesin tabung, tingkat pendidikan, dan tanggungan keluarga berpengaruh posistif dan signifikan terhadap pendapatan pengusaha depot air minum isi ulang di Kecamatan Tungkal Ilir Kabupaten Tanjung Jabung Barat. Apabila mesin tabung, tingkat pendidikan, dan tanggungan keluarga ditambah maka pendapatan pengusaha depot air minum isi ulang pun akan meningkat. Sedangkan variabel jam operasional sebesar 148272.1 tidak berpengaruh signifikan terhadap pendapatan pengusaha depot air minum isi ulang di Kecamatan Tungkal Ilir Kabupaten Tanjung Jabung Barat.

\section{KESIMPULAN DAN SARAN}

\section{Kesimpulan}

Berdasarkan data ini pengusaha depot air minum isi ulang yang ada di Kecamatan Tungkal Ilir dapat didefinisikan karakteristik sosial ekonomi responden pengusaha depot air minum isi ulang berdasarkan jenis kelamin mayoritas laki-laki sebesar 70 persen, umur diatas 41 tahun sebesar 40 persen, tingkat pendidikan S1 sebesar 43,34 persen, jumlah anggota keluarga 3-4 orang sebesar 36,67 persen, lama usaha 11-20 tahun sebesar 36,67 persen dan pendapatan pengusaha depot air minum isi ulang dari perolehan $\operatorname{Rp} 3.100 .000$ - Rp 4.000.000 sebesar 55 persen. Hasil pengolahan data pendapatan pengusaha depot air minum isi ulang akan meningkat diperoleh dari koefisien regresi masing-masing variabel mesin tabung sebesar 269477.4, tingkat pendidikan sebesar 148272.1, dan tanggungan keluarga sebesar 294857.1 variabel mesin tabung, tingkat pendidikan, dan tanggungan keluarga berpengaruh posistif dan signifikan terhadap pendapatan pengusaha depot air minum isi ulang. Sedangkan variabel jam operasional sebesar 148272.1 yang tidak berpengaruh signifikan terhadap pendapatan pengusaha depot air minum isi ulang di Kecamatan Tungkal Ilir Kabupaten Tanjung Jabung Barat.

\section{Saran}

Disarankan pada penelitian selanjutnya yang akan meneliti tentang pendapatan pengusaha depot air minum isi ulang diharapkan untuk mencari tempat penelitian yang lebih luas baik lokasi maupun kelompok jenis kegiatan lainnya. Pengaruh mesin tabung, tingkat pendidikan, dan tanggungan keluarga terhadap pendapatan pengusaha depot air minum isi ulang di Kecamatan Tungkal Ilir Kabupaten Tanjung Jabung Barat sangat signifikan, disarankan untuk Pemerintah Kabupaten berperan aktif untuk membantu kelancaran pengusaha depot air minum isi ulang dalam mengelola usahanya dengan memberikan bantuan modal dan permudah perizinannya.

\section{DAFTAR PUSTAKA}


A Mulyadi, H Hardiani, E Umiyati. (2018). Faktor-faktor yang mempengaruhi penyerapan tenaga kerja pada sektor industri kecil di Kabupaten Muaro Jambi, e-Jurnal Perdagangan Industri dan Moneter 6 (1), 35-44

Amir, Yulmardi dan Junaidi. (2009). Metodologi penelitian ekonomi dan penerapannya. IPB Press. Bogor.

Badan Pusat Statistik. (2019). Depot air minum isi ulang. Kabupaten Tanjung Jabung Barat Dalam Angka.

Firdaus, Muhammad. (2011). Ekonomitrika: Suatu Pendekatan Aplikatif. PT. Bumi Aksara. Jakarta.

Kemenkes RI. (2012). Tentang tata laksana pengawasan kualitas air minum

N Nurhayani, A Bhakti. (2014).Analisis disparitas pembangunan ekonomi dan hubungannya dengan investasi di Provinsi Jambi Tahun 2002-2014, Jurnal Paradigma Ekonomika 10 (2)

Purwanto, Slamet. (1995). Penyediaan air bersih. Jakarta.

Radji, M dan Heria, Herman. (2008). Pemeriksaan Bakteriologis air minum isi ulang di beberapa depo air minum isi ulang di Daerah Lenteng Agung dan Serengseng Sawah Jakarta Selatan. Majalah Ilmu Kaefarmasian.

Republika. Com. (2014). Penggunaan air dirumah tangga picu kelangkaan air. Diakses dalam https://www.republika.co.id/berita/nasional/umum/14/03/24/n2x3pqpenggunaan-air-di-rumah-tangga-picu-3kelangkaan-air-bersihAir, Tanggal 21 Agustus 2019.Pukul 10.00 WIB

Salim, Peter dan Yenny. (1991). Kamus bahasa indonesia kontemporer. Modern English Perss. Jakarta.

Simanjuntak, Nilson. (2001). Evaluasi kinerja sumber daya manusia. Refika Aditama. Bandung.

Sudaryanto. (2009). Cara mendirikan depot air minum yang murah tapi sehat. Dikases dalam www. Ampl.com. Tanggal 21 Agustus 2019.Pukul 10.00 WIB

Sugiyono, (2004). Statistik Menjadi Mudah Dengan SPSS 17. Elex Media Kompetindo. Jakarta.

Sutrisno. Totok. (2002). Teknologi penyediaan air bersih. Rineka Cipta. Jakarta.

Suyono, Budiman.(2010). Ilmu kesehatan masyarakat. EGC. Jakarta.

Umar, Husein. (2005). Metode penelitian untuk skripsi dan tesis bisnis. PT. Raja Grafindo Persada. Jakarta. 